\title{
Evaluation of Compressive Strength and Microhardness of Composites Associated to Light Curing Characterizing Materials
}

\author{
${ }^{1}$ Daphne Câmara Barcellos, ${ }^{2}$ Graziela Robeiro Batista, ${ }^{3}$ Patrícia Rondon Pleffken, ${ }^{4}$ Márcia Carneiro Valera \\ ${ }^{5}$ Carlos Rocha Gomes Torres, ${ }^{6}$ Maria Amélia Máximo de Araújo
}

\begin{abstract}
Aim: This study evaluated the microhardness and compressive strength of composite and light curing characterizing materials (LCCMS) by intrinsic technique.
\end{abstract}

Materials and methods: Eighty composite specimens with a cylindrical shape were prepared and divided into eight groups $(n=10)$ : Group E-composite-Enamel shade (ES); Group Tcomposite-Translucent shade (TS); Group W-White Tetric Color Pigment (Ivoclar/Vivadent) LCCM; G roup B-Black Tetric Color Pigment (Ivoclar/Vivadent) LCCM; Group E/W/E-TS/ White Tetric Color Pigment LCCM/ES; Group E/B/E-ES/ Black Tetric Color Pigment LCCM/ES; G roup E/W/T-ES/W hite Tetric Color Pigment LCCM/TS; Group E/B/T-ES/Black Tetric Color Pigment LCCM/TS. The specimens were submitted to a microhardness and compressive strength tests. Data were subjected to ANOVA, Tukey tests $(5 \%)$ and pearson correlation.

Results and conclusion: There were significant differences among the groups $(p=0.00)$. The Pearson correlation showed a $p=0.85$. The mean values for microhardness: Group E-73.30a; Group T-66.47b; Group E/W/T-63.71bc; Group E/W/E-62.08bc; Group E/B/E-57.47c; Group E/B/T-55.61c; Group W-39.69d; Group B-37.87d. The mean values for compressive strength: Group E-493.12a; Group T-481.96a; Group E/B/E - 359.45b; Group E/W/T-358.64b; Group E/B/T357.01b; Group E/W/E-353.73b; Group W-136.62c; Group $B-41.22 d$. The use of LCCM by intrinsic technique reduced the microhardness and compressive strength of composite. There is a strong correlation between microhardness and compressive strength.

Clinical significance: The use of light curing characterizing materials combined with direct resin restorations can adversely

\footnotetext{
${ }^{1}$ Postdoctoral Student, ${ }^{2,3} \mathrm{PhD}$ Student, ${ }^{4,6} \mathrm{Full}$ Professor ${ }^{5}$ Associate Professor

${ }^{1-3}$ C linical R esearch Academic Group, Department of Restorative Dentistry, Institute of Science and Technology, Universidade Estadual Paulista, São J osé dos Campos, São Paulo, Brazil

${ }^{4-6}$ Department of Restorative Dentistry, Institute of Science and Technology, Universidade Estadual Paulista, São J osé dos Campos, São Paulo, Brazil

Corresponding Author: Carlos Rocha Gomes Torres Associate Professor, Department of Restorative Dentistry São Paulo; Avenida Engenheiro Francisco, J osé Longo, 777 J ardim São Dimas, São J osé dos Campos, São Paulo, Brazil Phone: (12) 39479048, Fax: (12) 39479010, e-mail: carlosrgt@ fosjc.unesp.br
}

reduce microhardness and compressive strength of direct esthetic restorations.

Keywords: Composite, Light curing characterizing materials, Microhardness, Compressive strength.

How to cite this article: Barcellos DC, Batista GR, Pleffken $P R$, Valera MC, Torres CRG, de Araújo MAM. Evaluation of Compressive Strength and Microhardness of Composites Associated to Light Curing Characterizing Materials. World J Dent 2014;5(1):6-10.

\section{Source of support: $\mathrm{Nil}$}

Conflict of interest: None

\section{INTRODUCTION}

The intrinsic technique of direct esthetic dental restoration consists in applying, on the previously polymerized composite, light curing characterizing materials (LCCMs) in thin films $(<0.2 \mathrm{~mm}$ ) followed by polymerization to achieve characterization of direct and indirect composite restorations, such as occlusal grooves, modification of the chromatic tooth or dental hypoplasia. ${ }^{1-3}$ The LCCMs are also used to masking discolored tooth structure, to cover stains or metal, and to simulate white spots. ${ }^{1}$

These LCCMs present low filler content, so they exhibit low wear resistance, facilitating the loss of characterization after a short time due to the low inorganic filler of these tints. ${ }^{2,3}$ Therefore, it is recommended the external coating of the LCCMs with one or more resin layers. ${ }^{4}$

However, Pucci et $\mathrm{al}^{5}$ showed that LCCMs applied using the intrinsic technique can alter the mechanical properties of the composite, harming the cohesive strength at the composite interfaces, and promote a premature failure and compromise the durability of the restoration. They observed that darker pigmented LCCMs showed lower cohesive strength values when compared to white pigmented LCCMs.

Currently, composites exhibit a significant improvement in their mechanical properties, increasing the possibilities of its indication. Compressive tests consist to perform vertical stresses on the composites, in order to simulate the forces transmitted to the restorations during the chewing, which can fracture the restorative material and/or tooth. ${ }^{6-8}$ The microhardness expresses the resistance to permanent 
deformation of the composites, which is proportional to the mechanical strength and wear resistance of composites. ${ }^{9,10}$

Although these materials have been used in dental practice, there are no studies in the current literature that evaluated the possible detrimental effect in the microhardness and compressive strength of the composites when LCCMs are used with the intrinsic technique. The use of these tints may change the physical-mechanic properties of the composite, thus causing early failure and harming the durability of the dental restoration.

Therefore, this current study investigated a simple, but important question relative to the use of LCCMs combined with direct resin restorations, as it evaluated the microhardness and compressive strength of a composite when different LCCMs were applied with the intrinsic technique.

\section{MATERIALS AND METHODS}

The materials used and their compositions are shown in Table 1.

The intrinsic technique was performed with Filtek Z350 composite (3M ESPE, St. Paul, MN, USA), Enamel (shade A3) and Translucent opacities associated to Tetric Color LCCM (Ivoclar/Vivadent), White and Black pigments.

Eight experimental groups, with ten specimens each, were prepared and categorized:

1. Group E: Filtek Z350 XT composite (Enamel opacity) (3M ESPE, shade A3).

2. Group T: Filtek Z350 Filtek composite (Translucent opacity) (3M ESPE).

3. Group W: White Tetric Color pigment (Ivoclar/ Vivadent) LCCM.

4. GroupB: Black Tetric Color pigment (Ivoclar/Vivadent) LCCM.

5. Group E/W/E: Filtek Z350 XT composite (Enamel opacity)/White Tetric Color pigment (Ivoclar/Vivadent) LCCM/Filtek Z350 XT composite (Enamel opacity).

6. Group E/B/E: Filtek Z350 XT composite (Enamel opacity)/Black Tetric Color pigment (Ivoclar/Vivadent) LCCM/Filtek Z350 XT composite (Enamel opacity).
7. Group E/W/T: Filtek Z350 XT composite (Enamel opacity)/White Tetric Color pigment (Ivoclar/Vivadent) LCCM/Filtek Z350 Filtek composite (Translucent opacity).

8. Group E/B/T: Filtek Z350 XT composite (Enamel opacity)/Black Tetric Color pigment (Ivoclar/Vivadent) LCCM/Filtek Z350 Filtek composite (Translucent opacity).

Two-piece metallic devices with a $3 \mathrm{~mm}$ diameter and $6 \mathrm{~mm}$ height were developed for this work, which were inserted in a metal holder to keep the two halves in place during preparation of the composite specimens.

For the groups $\mathrm{E}$ and $\mathrm{T}$, the composite was inserted in the two-piece metallic devices with a $3 \mathrm{~mm}$ diameter and $6 \mathrm{~mm}$ height, using the incremental technique and light polymerized according to the manufacturer's specifications using an output intensity of $650 \mathrm{~mW} / \mathrm{cm}^{2}$ for 20 seconds (Curing Light XL 3000, 3M ESPE, St. Paul, MN, USA). The last increment was covered with polyester strips and microscope slide glass to obtain a flat surface, prior to polymerization.

For the groups B and W, the LCCM was inserted in increments not to exceed $0.5 \mathrm{~mm}$ of thickness and cured for 20 seconds. The last increment was covered following the same treatments described above.

For the groups E/W/E, E/B/E E/W/T e E/B/T, the composite Filtek Z350 XT composite (Enamel opacity) was inserted in the two-piece metallic devices with a $3 \mathrm{~mm}$ diameter and $5.6 \mathrm{~mm}$ height and light polymerized according to the manufacturer's directions. The two-piece teflon device with a $3 \mathrm{~mm}$ diameter and $0.2 \mathrm{~mm}$ height was positioned over the first half of the specimens, to standardize the amount of LCCM used for each specimen. A very thin layer of the LCCMs were applied on the composite interface with a brush (Brush 382, Tigre S/A, São Paulo, SP, Brazil), to complete the pre-established height. Each LCCM was activated according to manufacturer's instructions for 20 seconds. The two-piece teflon device with a $3 \mathrm{~mm}$ diameter and $0.2 \mathrm{~mm}$ height was placed over the LCCM

Table 1: P roducts, manufacturers and compositions

\begin{tabular}{|c|c|c|}
\hline Materials & Manufacturer & Composition \\
\hline $\begin{array}{l}\text { Filtek Z350 } \\
\text { composite }\end{array}$ & $\begin{array}{l}\text { 3M ESPE, } \\
\text { St. Paul, MN, USA }\end{array}$ & $\begin{array}{l}\text { Bis-GMA (Bisphenol A-glycidyl-methacrylate), UDMA } \\
\text { (urethane dimethacrylate), TEGDMA (triethyleneglycol } \\
\text { dimethacrylate), Bis-EMA (glycidyl ethoxylate dimethacry- } \\
\text { late), } 20 \mathrm{~nm} \text { nanosilica filler, agglomerates of primary } \\
\text { zirconia/silica particles with size of } 5 \text { to } 20 \mathrm{~nm} \text { fillers } \\
\text { ( } 78.5 \% \text { by weight) }\end{array}$ \\
\hline Tetric color & $\begin{array}{l}\text { Ivoclar/ } \\
\text { Vivadent, Schaan/ } \\
\text { Liechtenstein }\end{array}$ & $\begin{array}{l}\text { Bis-GMA ( }<36 \%), \text { UDMA ( }<33 \%), \text { TEG DMA }(<18 \%),(86 \% \\
\text { by weight), Silanized silicon dioxide ( } 12-13 \% \text { by weight), } \\
\text { catalyzers and pigments ( }<2 \% \text { by weight) }\end{array}$ \\
\hline
\end{tabular}


layer and a thin layer of the composite were applied on the LCCM to finalize the specimen. The last increment was covered following the same treatments described previously.

The specimens were stored in distilled water at $37^{\circ} \mathrm{C}$ for 15 days.

Vickers microhardness, at a load of $50 \mathrm{gm}$, with an indentation time of 10 seconds, was determined using a microhardness tester (FM-700, Future-Tech, Tokyo, Japan). Three indentations were performed on the surface of each specimen, with a distance of $50 \mu \mathrm{m}$ between them, and the mean Vickers hardness (VH) calculated.

Compressive strength of specimens was measured on a universal testing machine (EMIC 2000, São José dos Pinhais, PR, Brazil) with a load cell of $1000 \mathrm{kgf}$ and a crosshead speed of $0.5 \mathrm{~cm} / \mathrm{min}$. Data were tabulated and analyzed statistically using ANOVA and the Tukey test for pairwise comparisons. Significance level was set at 5\%.

A Pearson correlation analysis of the relationship between microhardness and compressive strength values was performed with a significance level of 0.05 .

\section{RESULTS}

For compressive strength, the ANOVA showed a p-value $=$ $0.0000(\mathrm{~F}=1596)$, with 7 degrees of freedom, which indicated the presence of significant differences between groups.

For microhardness, the ANOVA showed a $p$-value $=$ $0.0000(\mathrm{~F}=42.9)$, with 7 degrees of freedom, which indicated the presence of significant differences between groups.

The Table 2 shows the results of Tukey's Test for compressive strength. The group B, which is the control group for the Black pigment, resulted in lower values than other groups; the group $\mathrm{W}$, which is the White pigment control group, showed lower values than other except for group $\mathrm{B}$. The groups $\mathrm{E} / \mathrm{B} / \mathrm{E}, \mathrm{E} / \mathrm{W} / \mathrm{T}, \mathrm{E} / \mathrm{B} / \mathrm{T}$ e E/W/E, which the composite resin was associated to different pigments using intrinsic technique, resulted in values significantly lower than the groups $\mathrm{E}$ and $\mathrm{T}$, which were control for the different opacities of composite.
In Table 3 are the results of Tukey's Test for microhardness analysis. The groups $\mathrm{W}$ and $\mathrm{B}$, control of pigments have significative lower values than other groups. The groups $\mathrm{E} / \mathrm{B} / \mathrm{T}$ e $\mathrm{E} / \mathrm{B} / \mathrm{E}$, which associated the Black pigment to composite resin show lower values than enamel resin control group E and Translucent resin control group T.

Pearson's correlation test showed $\mathrm{p}$-value $=0.85$, that means strong correlation between the mechanical properties microhardness and compressive strength.

\section{DISCUSSION}

This study evaluated possible mechanical properties alterations when composite resins were associated to White and Black pigments using intrinsic technique for characterized direct restorations.

For compressive strength the results of this study showed that the groups B and W, which were control for pigments Black and White obtained significant lower values of compressive strength comparing to other groups. The increase of compressive strength values of composite resins is directly proportional to weight increase of inorganic components. ${ }^{11,12}$ The LCCMs are flowable composite resins, which have low concentration of inorganic filler (12-13\% $\mathrm{w} / \mathrm{v})$ and high concentration of organic filler $(86 \% \mathrm{w} / \mathrm{v})$. The low values for compressive strength obtained for black pigment (Group B) compared to other experimental groups can be elucidated because this low inorganic filler concentration $(12-13 \% \mathrm{w} / \mathrm{v})$, once the composite resin used to perform this study Filtek Z350 XT, opacities Enamel and Translucent, have about $78.5 \%$ and $72.5 \%(\mathrm{w} / \mathrm{v})$ of inorganic filler in their composition, giving them high resistance to compressive strength and wear. ${ }^{13,14}$ Beside this, the type and shape of particles (nanoparticles or 'clusters'), from Filtek Z350 XT composite, can influence the results, being necessary more studies to confirm this affirmation.

The results of this study also demonstrated that group B, which was the control for Black pigment, was significantly lower resistant to compressive tests than group $\mathrm{W}$, the control

Table 2: Tukey's test results, mean and standard deviation of compressive strength for experimental groups

\begin{tabular}{|c|c|c|}
\hline Groups & Mean $( \pm S D)$ & Homogeneous groups* \\
\hline Group E & $493.12( \pm 12.73)$ & A \\
\hline Group T & $481.96( \pm 12.56)$ & $A$ \\
\hline Group E/B/E & $359.45( \pm 16.47)$ & B \\
\hline Group E/W/T & $358.64( \pm 15.65)$ & B \\
\hline Group E/B/T & $357.01( \pm 12.94)$ & B \\
\hline Group E/W/E & $353.73( \pm 14.28)$ & B \\
\hline Group W & $136.62( \pm 9.61)$ & C \\
\hline Group B & $41.229( \pm 8.06)$ & D \\
\hline
\end{tabular}

*Means followed by same letters do not show significant statically difference 
Table 3: Tukey's test results, mean and standard deviation of microhardness

\begin{tabular}{|c|c|c|c|}
\hline \multicolumn{4}{|c|}{ Mean (+ts) } \\
\hline Group E & $73.30( \pm 6.95)$ & $A$ & \\
\hline Group T & $66.47( \pm 4.63)$ & A & \\
\hline Group $\mathrm{E} / \mathrm{W} / \mathrm{T}$ & $63.71( \pm 7.47)$ & B & C \\
\hline Group E/W/E & $62.08( \pm 6.02)$ & B & C \\
\hline Group $E / B / E$ & $57.47( \pm 3.96)$ & & C \\
\hline Group $E / B / T$ & $55.61( \pm 5.11)$ & & C \\
\hline Group W & $39.69( \pm 7.61)$ & & D \\
\hline Group B & $37.874( \pm 7.70)$ & & $\mathrm{D}$ \\
\hline
\end{tabular}

for White pigment. Pucci et $\mathrm{al}^{5}$ watched that darkiest LCCMs can significantly reduce the values of cohesive resistance comparing to clear colors of LCCMs, when used between layers of composite resin.

The authors believe these results occur because of the pigments in the LCCMs. Swartz et al, ${ }^{15}$ Ferracane et al, ${ }^{16}$ Vinha et al, ${ }^{17}$ Backer et $\mathrm{al}^{18}$ and Takamizu et $\mathrm{al}^{19}$ observed that clear colors composite resin, shown deeper cure compared to dark colors composite resins. Therefore, probably the black pigment can select and filter some length wave from light-curing device. ${ }^{20}$

Additionally, Friedman and Hassan ${ }^{20}$ evaluated the correlation between composite resin colors and conversion degree from monomers to polymers, and concluded that is more difficult to convert composite resins which have high quantity of pigments.

The groups E/B/E, E/W/T, E/B/T and E/W/E, that used composite resin associated to different LCCMs employing intrinsic technique shown significant lower values than group E, which was control for Enamel opacity composite resin, and than group T, which was control for Translucent opacity composite resin. Pucci et $\mathrm{al}^{5}$ believe there is some kind of incompatibility between composite resins and LCCMs, beside this, the lower concentration of inorganic filler and the pigments in the LCCMs can affect the cohesion strength between them. Based in the results of this study, it is possible to note that even in lower quantities $(0.2 \mathrm{~mm}$ thickness), the LCCMs are capable of reduce significantly compressive strength when associated to composite resins employing intrinsic technique.

Regarding microhardness, our results demonstrating that group W, which was the control for white color LCCM, and the group B, which was control for black color LCCM, showed significant lower values than other experimental groups. Ratifying these results, previous studies ${ }^{21,23}$ affirm that superficial microhardness increase is directly proportional to increase of inorganic filler (weight). The LCCMs black and white have around 12 to $13 \%$ of inorganic filler in full weight, while composite resin Filtek Z350 XT opacities for enamel and translucent colors (groups E and T), which showed the better values for this study, have in their composition 78.5 and $72.5 \%$ of inorganic filler respectively. Additionally, other studies ${ }^{24,25}$ observed that polymerization degree directly influence the hardness variation of Bis-GMA based composite resins.

As LCCMs composition shows high quantities of pigments, the conversion degree from monomers to polymers could be reduced, compromising superficial microhardness of these materials.

The results obtained for this study, show that the association of composite resin to LCCM black performed by intrinsic technique (groups $\mathrm{E} / \mathrm{B} / \mathrm{T}$ and $\mathrm{E} / \mathrm{B} / \mathrm{E}$ ) showed significant lower values than group $\mathrm{E}$ and $\mathrm{T}$, which were control groups for different opacities, probably because the light curing device capacity of select and filter some wave lengths, ${ }^{20}$ decreasing polymerization deeper ${ }^{15-19}$ and its conversion degree from monomers to polymers. Thus, darker LCCMs can significantly reduce superficial microhardness, when used by intrinsic technique compared to more clear LCCMs, even when employed enamel or translucent opacities of Filtek Z350 XT composite resin ( $0.2 \mathrm{~mm}$ thickness) over black LCCMs in the same thickness $(0.2 \mathrm{~mm})$. However, it is necessary to perform more studies to elucidate the results obtained from this study.

For the relation between mechanical properties microhardness and compressive strength, Pearson's correlation test $(\mathrm{p}=0.85)$ showed positive and direct correlation between these mechanical properties.

Confirming the founds of this study, previously studies, ${ }^{26-28}$ stated there is direct relation between microhardness and resistance properties of materials. Being the superficial microhardness an indication of other mechanical properties of materials, as compressive strength for example, their values must be high initially and throughout the clinical life of restoration. However, other authors $^{29}$ affirm that compressive strength is a complex 
phenomenon and cannot be associated to microhardness mechanical property.

Indeed, the quality of restorative material cannot be evaluated only according two isolated mechanical properties results. The success of restoration depends of aggregate properties that must be present in direct esthetic restoration: physical, mechanical, esthetics, biophysical and biologics. Thereby, more results must be performed to watch composite resins behaviors when employed associated to LCCMs using intrinsic technique for esthetic direct characterized composite resin restorations.

\section{CONCLUSION}

According the results of this study for composite resin Filtek Z350 XT (3M ESPE) associated to LCCMs performed by intrinsic technique for characterized esthetic direct resin restoration, it is possible to conclude that:

The use of white and black LCCMs reduce significantly compressive strength of direct esthetic restorations.

The use of black LCCMs reduce significantly microhardness of direct esthetic restorations.

There is high correlation between mechanical properties microhardness and compressive strength.

\section{REFERENCES}

1. Preston J, Bergen S. Color science and dental art. St Louis; Mosby, 1980.

2. Itoh K, Iwaku M, Fusayama T. Effectiveness of glazing composite resin restorations. J Prosthet Dent 1981; 45: 606-613.

3. Lambrechts P, Vanherle G. The use of glazing materials for finishing dental composite resin surfaces. J Oral Rehabil 1982; 9:107-117.

4. Black J. Aesthic restorations of tetracycline-stained teeth. J Amer Dent Assoc 1982; 104: 846-852.

5. Pucci CR, Barcellos DC, Palazon M, Borges AB, Silva MS, Goncalves SEP. Evaluation of cohesive strength between resin composite and light curing characterizing. J Adhes Dent 2011; 13 (In press).

6. Baharav H, Abraham D, Cardash HS, Helft M. Effect of exposure time on the depth of polimerization of a visible light cured composite resin. J Oral Rehabil 1988; 15(2):167-172.

7. Roulet JF. The problems associated with substituting composite resins for amalgam: a status report on posterior composites. J Dent 1988;16(3):101-113.

8. Oliveira Fde C, Denehy GE, Boyer DB. Fracture resistance of endodontically prepared teeth using various restorative materials. J Am Dent Assoc 1987;115(1):57-60.

9. Willems G, Lambrechts P, Braem M, Vanherle G. Composite resins in the 21st century. Quintessence Int 1993 Sep;24(9): 641-658.

10. Satou N, Khan AM, Satou K, Satou J, Shintani H, Wakasa K, Yamaki M. In vitro and in vivo wear profile of composite resins. J Oral Rehabil 1992 Jan;19(1):31-37.
11. Peutzfeldt A, Asmussen E. The effect of postcuring on quantity of remaining double bonds, mechanical properties, and in vitro wear of two resin composites. J Dent 2000;28(6):447-452.

12. Brosh T, Ganor Y, Belov I, Pilo R. Analysis of strength properties of light-cured resin composites. Dent Mater 1999 May;15(3):174-179.

13. Mitra SB, Wu D, Holmes B. An application of nanotechnology in advanced dental materials. J Am Dent Assoc 2003;134(10): 1382-1390.

14. Yap AU, Tan CH, Chung SM. Wear behavior of new composite restoratives. Oper Dent 2004;29(3):269-274.

15. Swartz ML, Phillips RW, Rhodes B. Visible light-activated resins-depth of cure. J Am Dent Assoc 1983;106:634-637.

16. Ferracane JL, Aday P, Matsumoto H, Marker VA. Relationship between shade and depth of cure for light-activated dental composite resins. Dent Mater 1986;2:80-84.

17. Vinha D, Coelho MT, Maia Campos G. Efficacy of some devices generate of visible light curing composite. [In Portuguese]. Rev Bras Odont 1990;47:10-14.

18. Backer J, Dermaut L, Bruynooghe W. The depth of polymerization of visible light-cured composite resins. Quintessence Int 1985; 16:693-701.

19. Takamizu M, Moore BK, Setcos JC, Phillips RW. Efficacy of visible-light generators with changes in voltage. Oper Dent 1988;13:173-180.

20. Friedman J, Hassan R. Comparison study of visible curing lights and hardness of light-cured restorative materials. J Prosthet Dent 1984;52:504-506.

21. Neves AD, Discacciati JA, Orêfice RL, Jansen WC. Correlation between degree of conversion, microhardness and inorganic content in composites. [Article in Portuguese] Pesqui Odontol Bras 2002 Oct-Dec;16(4):349-354.

22. Anfe TE, Caneppele TM, Agra CM, Vieira GF. Microhardness assessment of different commercial brands of resin composites with different degrees of translucence. Braz Oral Res 2008 OctDec;22(4):358-363.

23. Scougall-Vilchis RJ, Hotta Y, Hotta M, Idono T, Yamamoto K. Examination of composite resins with electron microscopy, microhardness tester and energy dispersive $\mathrm{X}$-ray microanalyzer. Dent Mater J 2009 Jan;28(1):102-112.

24. Quance SC, Shortall AC, Harrington E, Lumley PJ. Effect of exposure intensity and post-cure temperature storage on hardness of contemporary photo-activated composites. J Dent 2001; 29(8):553-560.

25. Martins F, Delbem ACB, Santos LRA, Soares HLO, Martins EOB. Microdureza de resina em função da cor e luz halógena. Pesqui Odontol Bras 2002;16(3):246-250.

26. Willems G, Lambrechts P, Braem M, Celis JP, Vanherle G. A classification of dental composites according to their morphological and mechanical characteristics. Dent Mat 1992; 8(9):310-319.

27. Anusavice KJ. Phillips materiais dentários. Rio de Janeiro: Guanabara Koogan 2005.

28. Tantbirojn D, Cheng YS, Versluis A, Douglas WH. Microhardness and fracture toughness of a composite, are they related? J Dent Res 2000; 79(Sp Issue): 443. abstr 2398.

29. Harrison A, Draughn RA. Abrasive wear, tensile strength and hardness of dental composite resins - Is there a relationship? J Prosth Dent 1976;36(4):395-398. 